\title{
What practice can learn from theory: The potential impact of disposition decision factors on organisational performance
}

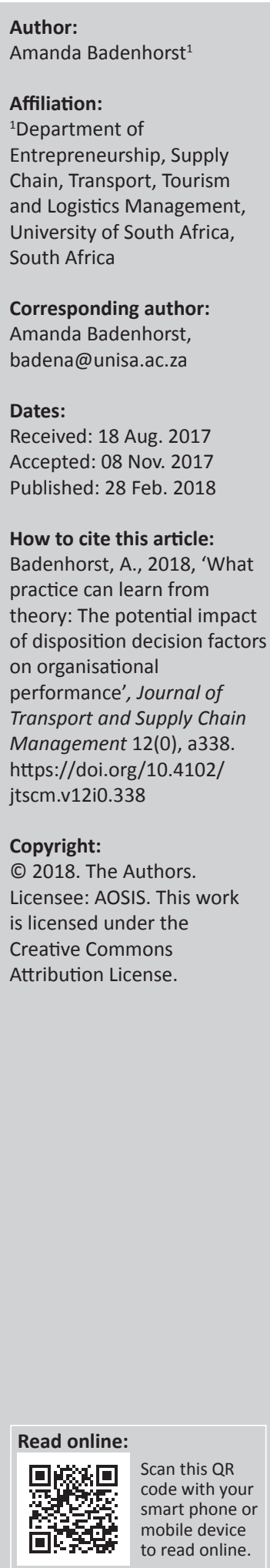

Background: Effective disposition decisions can lead to a number of value-adding benefits including economic, environmental and marketing benefits. Despite this, many organisations are not aware of the importance of disposition decisions and the impact they can have on organisational performance.

Objectives: The aim of this study was to demonstrate the potential impact of disposition decision factors on organisational performance.

Method: This study made use of a qualitative content analysis method on previously published scientific articles on reverse logistics. The sample included 67 published scientific articles between 2006 and 2016. ATLAS.ti software was used to assist with the data analysis process.

Findings: The findings showed a number of factors for disposition decision-making resulting in a number of value-adding benefits, which can improve organisational performance. From the findings, a conceptual framework was developed linking the disposition decision factors with the value-adding benefits and areas of organisational performance improvements.

Conclusion: The framework developed in this article contributes to new insights and can help organisations to identify different performance improvement areas associated with certain disposition decision factors.

\section{Introduction}

\section{Background}

The importance of product recovery and disposition in reverse logistics has grown in the past few decades (Niknejad \& Petrovic 2014:143) because of economic reasons, environmental concerns and corporate responsibility (Selvi \& Kayar 2016:26). This strong involuntary push towards economic gain and environmental awareness has caused more organisations to focus on reverse logistics and seek out avenues to attain value from the products they must take back (Huscroft et al. 2013:319). Reverse logistics is the process of collection, inspection, sorting and disposition of returned and/or used products from the consumer to a retailer or manufacturer. The aim is to realise economic, environmental, marketing and social benefits in the supply chain. Benefits can only be realised if correct disposition options are made and the return of products is done effectively (Agrawal, Singh \& Murtaza 2016c:944).

Economic benefits can be realised through generating revenue and reclaiming value from returned products (Agrawal, Singh \& Murtaz 2016b:94; Khor et al. 2016:97; Shaharudin, Zailani \& Tan 2015:222). Environmental benefits can, for example, be realised through product recovery that prevents returned products from going into landfill (Ravi \& Shankar 2015:12), thus reducing waste and environmental damage (Khor \& Udin 2012:4; Shaharudin et al. 2015:221). Finally, the product recovery disposition option can also lead to marketing benefits, as it can result in a competitive advantage, create market opportunities and improve customer satisfaction (Ravi \& Shankar 2015:17).

Despite these value-adding benefits, businesses and researchers have overlooked the potential of reverse logistics and recovery or disposition, especially in developing nations such as South Africa. Badenhorst (2016:10) found that a limited number of organisations specialise and understand reverse logistics in South Africa. In fact, organisations in developing countries perceive reverse logistics disposition activities as a grave burden on scare resources (Shaharudin et al. 2015:221). Therefore, the conclusion can be made that there is a limited awareness of the potential and 
impact of effective disposition decisions on organisational performance. With regard to research, Agrawal et al. (2016b:93) noticed that only few studies focus on the disposition of returned products in reverse logistics. In addition, Agrawal et al. (2015:89) stated that disposition decisions offer a great potential for future research. It is therefore an important potential research focus area in reverse logistics, because returns have become an endemic part of doing business and there is a need to understand product disposition (RuizBenítez, Ketzenberg \& Van der Laan 2014:54).

\section{Previous research}

In reviewing the literature, it was noticed that a limited number of studies in reverse logistics focus on the impact that effective disposition decisions could have on organisational performance. A few studies could be found that focus on disposition decisions in general. For instance, Agrawal et al. (2016c) created a framework for optimal disposition decisions in reverse logistics. These authors used a combination of the analytical hierarchy process (AHP) and the fuzzy technique for order preference by similarity to ideal solution (TOPSIS) approach for the selection of disposition options. Their focus was therefore not on the impact of disposition decisions on organisational performance, but rather on the selection of disposition options.

Similarly, Ferguson, Fleischmann and Souza (2011) addressed disposition decisions made by manufacturers. The authors developed single-period and multiperiod stochastic optimisation models for disposition problems. In addition, they proposed a profit maximisation perspective to the problem of making optimal disposition decisions for product returns in a closed-loop supply chain of electronic products (Ferguson et al. 2011:792).

Dehghanbaghi, Hosseininasab and Sadeghieh (2016) used a fuzzy rule-based system and fuzzy AHP to provide a correct and accurate decision-making mechanism for ranking the recovery and/or disposal strategies by knowledge acquisition for each particular returned product. Similar to other studies, these authors focussed only on correct disposition decisions, but neglected the impact it can have on organisational performance.

A study closely related to this article is that of Hazen, Hall and Hanna (2012). These authors used a content analysis on reverse logistics literature to identify critical components of the reverse logistics disposition decision-making process and suggest a decision framework that may guide future investigation and practice (Hazen et al. 2012:244). Similarly, to the other studies mentioned above, these authors also focussed on disposition decision-making, without indicating the impact on organisational performance.

Limited studies in reverse logistics have used a qualitative content analysis (QCA) method on previous publications. As mentioned, Hazen et al. (2012) used a content analysis on reverse logistics literature to investigate disposition decisionmaking. Pokharel and Mutha (2009), Agrawal et al. (2015), Gonçalves and Silva (2016) and Govindan, Soleimani and Kannan (2015) all conducted content analysis literature reviews on reverse logistics publications to identify gaps and to suggest future research opportunities.

Although a QCA type of research on reverse logistics is rather limited, the method has been used quite often in supply chain literature. For instance, Stock and Boyer (2009) used a QCA of literature to determine important components of supply chain definitions in order to provide a consensus definition of supply chain management. In addition, Abbasi and Nilsson (2012) used a QCA on articles to explore themes and challenges in making supply chains environmentally sustainable. Similarly, Santos and D'Antone (2014) conducted a QCA of published articles on interfaces between intra-firm departments to identify the dimensions of demand-supply alignment and map the drivers, enablers and consequences of implementing such an alignment. Therefore, QCA on published literature has proved to be an appropriate approach to create new insights in logistics and supply chain management.

\section{Objectives and contribution}

As evident from the previous section, the focus of studies in reverse logistics is mostly on different disposition decisions, without studying the impact it can have on organisational performance. There is an obvious gap in research in this regard. Research is necessary to draw the attention of the researchers and the business community on the possible impact of product disposition on organisational performance. Hazen et al. (2012:248) stated that organisations should not only understand the factors that influence disposition decisions, but also recognise the potential gains that may be realised through considering these factors. Starostka-Patyk et al. (2013:508) found that managers do not have enough knowledge about reverse logistics and the kind of value-adding benefits that organisations can realise through product recovery practices. In addition, Shaharudin et al. (2015:221) mentioned that it is vital to educate practitioners on the value of effective disposition decisions as a unique form of competitive advantage and value creation from returned products.

Based on the perceived gaps in the literature and practice, the purpose of this article is to demonstrate the potential impact of disposition decision factors on organisational performance. This study will make use of a QCA on reverse logistics publications to (1) explore disposition decision factors, (2) identify the value-adding benefits associated with the disposition decision factors and (3) create a conceptual framework linking the disposition decision factors with the value-adding benefits and areas of organisational performance improvements.

The remainder of this article will include an overview of disposition as part of the reverse logistics process, followed by a description of the research methodology. The findings of the QCA will then be presented, followed by a presentation 
of the conceptual framework. Finally, the article highlights the limitations of the research, future research opportunities and a conclusion.

\section{Overview of the disposition process}

Reverse logistics is the overall process that starts at end users (consumers) where used and unused products are collected from customers and then decisions are made to manage the returned products through different disposition options (Govindan et al. 2015:603). Reverse logistics involves a number of key processes (Agrawal et al. 2015:77) such as product collection, inspection, sorting and disposition.

Disposition is the final process in reverse logistics (Agrawal et al. 2015:78) and refers to the exit route that the returned product will take (Bernon, Rossi \& Cullen 2011:492). Disposition involves different options, all with different revenue streams and recovery levels (Rogers, Melamed \& Lembke 2012:108). For instance, if a product is non-defective, the most value can be recovered because the product can be sold as new again. On the other hand, if the product is defective, more effort and cost will be involved in repairing or reconditioning the product in order to restore it; thus, it will have a lower recovery rate in comparison to direct reuse. The disposition options can be categorised as reuse, product upgrade, material recovery and waste management (Hazen et al. 2012:248). Each of these categories will be discussed in the rest of this section.

\section{Reuse}

The first option entails reusing or reselling the returned product in its current condition. In the reuse option, products are returned directly to inventory or repackaged (Stock \& Mulki, 2009:42). Direct reuse allows the most value to be recovered and is an option that presents itself when a customer returns an unused product (Hazen et al. 2012:248).

\section{Product upgrade}

The second category involves product upgrade with options such as repairing, reconditioning, refurbishing and remanufacturing. Product upgrade implies improving the product from its end-of-life or end-of-use condition to a condition that is acceptable for future use or sale (Hazen et al. 2012:249).

Repair involves the work of fixing and replacing malfunctioning components of a product in order to restore the existing used product to a working order (Khor \& Udin 2012:7).

Reconditioning involves some levels of product disassembly in order to restore the existing used product to a specific working condition by testing and repairing or replacing some components that have failed (Khor \& Udin 2012:7).

Refurbishing is the replacement of dated parts or components with a more advanced technology (Chan,
Chan \& Jain 2012:1324). Therefore, returned products are brought up to a specified quality level. The product is disassembled into modules and after those modules are inspected, they are fixed or replaced (Şükrü, Akdoğan \& Coşkun 2012:1642).

In remanufacturing, products can be transformed to keep original characteristics (Guo 2010:927). Remanufacturing is similar to refurbishing where the purpose is to increase the quality of the returned products or parts. However, the major difference is the degree of improvement, because remanufacturing requires more extensive testing and repairing (Chan et al. 2012:1324). Remanufacturing can therefore be described as the process of restoring used products to at least Original Equipment Manufacturer (OEM) performance specifications. It involves complete product disassembly before proceeding with extensive testing, restoration and replacement of worn-out or outdated components (Khor \& Udin 2012:7).

\section{Material recovery}

Material recovery involves recovering any portion of a returned product that may contain value (Hazen et al. 2012:249). In other words, material recovery includes recycling, which involves recovering parts or extracting recyclable materials for reuse (Chan et al. 2012:1324; Hazen et al. 2012:249). In the previous processes, the identity and functionality of returned products are retained as much as possible, but in recycling, materials are reused in the production of new parts; thus, the identity of the product is lost (Şükrü et al. 2012:1642).

\section{Waste management}

Waste management is an option when an organisation decides that there is no longer value to reuse, upgrade or to recover the materials and the product becomes waste (Hazen et al. 2012:249). The option in waste management is disposal, which involves landfilling or incinerating parts or products on the condition that other disposition options are no longer available and not worthy of recovery and sales at aftermarket (Khor \& Udin 2012:7). Therefore, non-recoverable products are disposed without any further value recovery (Gandolfo \& Sbrana 2008:34). Disposal should be the last resort and should only occur when the previously mentioned options are no longer available (Bonev 2012:21). Figure 1 provides a basic illustration of the disposition option process in reverse logistics.

Figure 1 illustrates the disposition option categories based on the type of returns and/or product condition. It also illustrates the main parties involved in the process. For example, if a consumer returns an unused product because of dissatisfaction to the retailer, the most likely disposition option would be reuse. Therefore, the product remains at the retailer and is placed back in stock. However, if the product is defective, product upgrade options might be more appropriate. Note from the figure that the manufacturer 


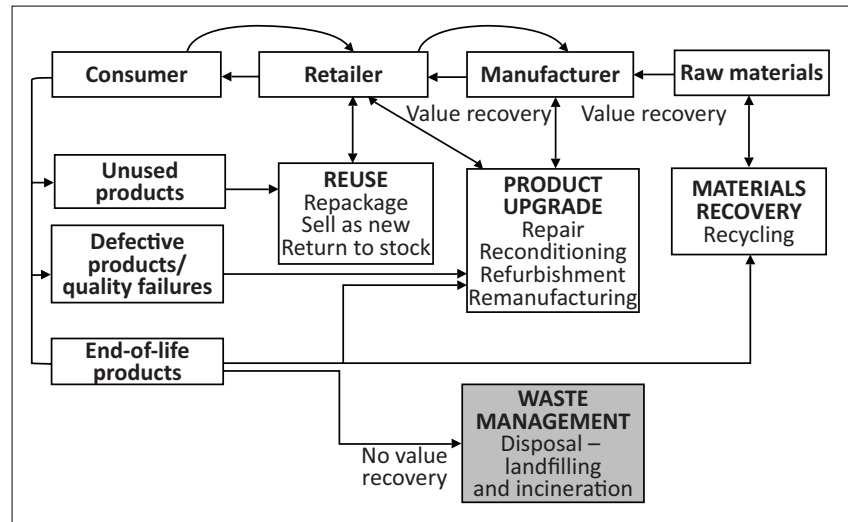

FIGURE 1: Disposition process in reverse logistics.

is normally responsible for product upgrades because of product knowledge. However, the retailer could also be involved in options such as repair, where the product can be sent back to the final consumer. If the product has reached its end of useful life, and depending on its condition, various options are available. These include refurbishment, remanufacturing, recycling and even disposal. In recycling, the product loses its identity and becomes raw material, which could be used as inputs to production. All the options except disposal involve recovery and organisations can gain financial value from the disposition operations. Although this illustration indicates the type of returns and/or product condition associated with disposition options, there are other disposition decision factors that organisations need to consider. This article will investigate these disposition decision factors that could lead to improved organisational performance.

\section{Research methodology}

The research method of this study was a QCA. Content analysis has three distinguishing characteristics:

1. It is an empirically grounded method.

2. It is exploratory in process.

3. It is predictive or inferential in intent (Krippendorff 2013:16).

As a research technique, content analysis provides new insights and increases a researcher's understanding of a particular phenomenon or informs practical actions (Krippendorff 2013:39). Content analysis is a method that may be used with either qualitative or quantitative data in an inductive or deductive way (Elo \& Kyngäs 2008:109). This study made use of QCA because it helps with the analysis and description of the most important characteristics of a large amount of qualitative data (Schreier 2012:41). In addition, QCA also enables a researcher to describe material in considerable depth (Schreier 2012:44). Furthermore, it can aid in comparing content across many sources and help to reveal aspects of the content that may be difficult to see when viewing phenomena in the context and scope of other research methods (Hazen et al. 2012:265). Qualitative content analysis is divided into a series of steps (Schreier 2012:17):
(1) deciding on a research question, (2) sampling and data collection, (3) data coding and analysis, (4) interpreting the data and (5) presenting the findings.

\section{Deciding on a research question or objective}

It is important to start with a clear research objective or question, because the results are directly linked to it (Mayring 2014:10). As the aim of this article was to demonstrate the potential impact of disposition decision factors on organisational performance, the following research questions were used to guide the research:

- What are the disposition decision factors that organisations need to consider when making disposition decisions?

- What are the value-adding benefits associated with the disposition decision factors?

- What is the impact of disposition decision factors on organisational performance?

\section{Sampling and data collection}

The material was selected through non-probability purposive sampling in order to reach the research objectives (Saunders, Lewis \& Thornhill 2012:287). The content analysis was restricted to scientific journals, because textbooks, working and conference papers and internet articles may go through less rigorous review processes (Santos \& D'Antone 2014: 1014). An initial search was made using Google Scholar for publications that contain either content analysis on reverse logistics literature or literature reviews in reverse logistics. This was performed to identify appropriate accredited peer review journals that were previously used by other scholars. The journals were identified based on the research of Hazen et al. (2012), Govindan et al. (2015) and Agrawal et al. (2015).

Most of the journals were identified from Science Direct, Emerald, Tandofline, Wiley online library, Proquest and Springer Link databases. Using the relevant databases and journals, the keywords 'reverse logistics', 'disposition decisions' and 'product recovery' were entered. Only articles between 2006 and 2016 were included in the search. This was done because other studies with similar methodologies used a date range of 10 years. The articles were then scanned and recorded on an Excel spreadsheet. Only those articles that contain content relevant to answer the research questions were included in the sample. Table 1 contains the journals, the number of articles and final sample size.

The sample size amounted to 33 journals and a total of 67 published articles between the years of 2006 and 2016.

\section{Data coding and analysis}

ATLAS.ti was employed to analyse the content. ATLAS.ti belongs to the genre of Computer-Aided Qualitative Data Analysis Software (CAQDAS) programs. Like other 
TABLE 1: Sample.

\begin{tabular}{|c|c|c|}
\hline Number & Journals included in the sample & $\begin{array}{l}\text { Number of } \\
\text { articles }\end{array}$ \\
\hline 1 & International Journal of Production Research & 8 \\
\hline 2 & $\begin{array}{l}\text { International Journal of Physical Distribution \& Logistics } \\
\text { Management }\end{array}$ & 6 \\
\hline 3 & The International Journal of Logistics Management & 5 \\
\hline 4 & International Journal of Production Economics & 5 \\
\hline 5 & $\begin{array}{l}\text { International Journal of Advanced Manufacturing } \\
\text { Technology }\end{array}$ & 3 \\
\hline 6 & Computers and Industrial Engineering & 3 \\
\hline 7 & Journal of Cleaner Production & 3 \\
\hline \multirow[t]{9}{*}{8} & Benchmarking: An International Journal & 2 \\
\hline & European Journal of Operational Research & 2 \\
\hline & Industrial Marketing Management & 2 \\
\hline & $\begin{array}{l}\text { International Journal of Logistics Research and } \\
\text { Applications }\end{array}$ & 2 \\
\hline & Journal of Business Logistics & 2 \\
\hline & Journal of Industrial Engineering International & 2 \\
\hline & Omega & 2 \\
\hline & Resources, Conservation and Recycling & 2 \\
\hline & Supply Chain Management Review & 2 \\
\hline \multirow[t]{19}{*}{9} & Business Horizons & 1 \\
\hline & Computers and Operations Research & 1 \\
\hline & $\begin{array}{l}\text { Corporate Social Responsibility and Environmental } \\
\text { Management }\end{array}$ & 1 \\
\hline & Decision Sciences & 1 \\
\hline & $\begin{array}{l}\text { International Journal of Core Engineering \& } \\
\text { Management }\end{array}$ & 1 \\
\hline & $\begin{array}{l}\text { International Journal of Research in Business \& Social } \\
\text { Science }\end{array}$ & 1 \\
\hline & International Journal of Supply Chain Management & 1 \\
\hline & International Journal of Sustainable Engineering & 1 \\
\hline & $\begin{array}{l}\text { International Journal of System Assurance Engineering } \\
\text { and Management }\end{array}$ & 1 \\
\hline & Journal of Business Economics & 1 \\
\hline & Journal of Modelling in Management & 1 \\
\hline & $\begin{array}{l}\text { Journal of Supply Chain and Customer Relationship } \\
\text { Management }\end{array}$ & 1 \\
\hline & Management Research Review & 1 \\
\hline & Production and Operations Management & 1 \\
\hline & Supply Chain Management: An International Journal & 1 \\
\hline & Uncertain Supply Chain Management & 1 \\
\hline & Waste Management & 1 \\
\hline & Total number of articles & 67 \\
\hline & Number of journals & 33 \\
\hline
\end{tabular}

CAQDAS programs, it does not actually analyse data, but is used as a tool for supporting the process of QCA (Friese 2014:1). The software enables a researcher to create codes, assign codes to passages and to retrieve results in various ways (Schreier 2012:252).

A coding frame was developed based on the objectives of this study. Two main codes were used to code the data including (1) disposition decision factors and (2) value-adding benefits focussing on organisational improvement areas related to disposition decision factors. All the articles were read and codes were assigned to relevant content over a period of a month in December 2016. Within each code category, several subcategories were identified during the coding process. After the coding, output reports were created. ATLAS.ti allows a researcher to create output reports for each code category, providing quotations (passages from literature) relevant to the code category to assist with the analysis process.

\section{Presenting the findings}

The final step of the QCA involves the presentation of the findings. According to Schreier (2014:233), in case of large amounts of data, it may be cumbersome to describe and illustrate every category using continuous text. Therefore, tables containing text (text matrices) can be used, which provides an overview of the categories. In addition, the interpretation of the findings can be discussed based on the content presented in the tables. This approach was followed in presenting the findings.

\section{Trustworthiness}

Reliability is a classic evaluation criteria commonly used in quantitative research but it can be used in qualitative research (Eriksson \& Kovalainen 2008:304). In the QCA method, reliability can be achieved by either using different coders (two researchers coding the data) or one researcher coding at different points in time (Schreier 2014:261). The latter option was applied to the study by conducting two rounds of trial coding. Therefore, the codes were applied to the same material by the researcher on two separate occasions, approximately 10-14 days apart (Schreier 2014:19). This was performed to determine if the results of the two coding rounds are similar, which ensured reliability of the findings.

ATLAS.ti adds to trustworthiness of qualitative research. It permits the researcher to apply multiple approaches to enhance the level of rigour in qualitative research (Atlas.ti 2017). Friese (2012:1) also stated that ATLAS.ti increases the validity of research results. Trustworthiness in qualitative research is normally associated with credibility, transferability, dependability and confirmability (Eriksson \& Kovalainen 2008:307).

ATLAS.ti can improve the credibility of qualitative findings, because it assists in providing rich descriptions in the narrating component of the QCA. This is done by making the relevant data or quotations that are directly linked to the themes (categories) of the research, readily available (Ducharme 2013:6). In addition, the data were based on 67 published articles, dealing with disposition decisions in reverse logistics, which contributed to the credibility of the study.

Dependability is associated with offering information to the reader, ensuring that the process of research has been logical, traceable and documented (Eriksson \& Kovalainen 2008:307). This was achieved by following a QCA method as described earlier as well as using ATLAS.ti to document the findings. Transferability refers to a researcher's responsibility to show a degree of similarity between his or her research, or parts of it, and other research, in order to establish a connection between results (Eriksson \& Kovalainen 2008:307). 
Transferability was achieved by using other studies with similar methodologies in the same field as a basis for the QCA of this study.

Confirmability refers to the idea that the data and interpretations of an inquiry are not just based on imagination. Therefore, it is about linking findings and interpretations to the data in ways that can be easily understood by others (Eriksson \& Kovalainen 2008:307). As published articles were used, sources can be traced to show that the findings are confirmable. In addition, the findings and analysis are presented in a manner that will enable readers to make sense of the various sources of data.

\section{Findings of content analysis on reverse logistics literature}

In this section, the findings of the content analysis are presented. The findings cover the disposition decision factors as well as the value-adding benefits associated with the disposition decisions factors.

\section{Disposition decision factors}

In reviewing the literature, it emerged that an important requirement for disposition decisions is to consider a variety of external and internal factors. These factors need to be taken into account to make the correct disposition decision, which may result in improved organisational performance. Certain categories and subcategories emerged from the content, which are presented in Table 2.

Each of these identified categories will be discussed next.

\section{Market-related factors}

Market-related factors are related to the markets, competition, industry and consumers. Firstly, brand-specific factors include brand image and brand protection. Organisations need to consider their brand image when reselling recovered products because of lower quality after recovery. In terms of brand protection, an example was given by Ruiz-Benítez et al. (2014:55), stating that an OEM might request from retailers to return products directly back to it for brand protection purposes.

Secondly, consumer-related factors are mostly related to consumer behaviour and/or consumer demand. For example, disposition decisions will be influenced by the willingness of consumers to return end-of-life products needed for product recovery activities. On the other hand, there might be a demand for recovered products, which organisations need to consider. By identifying the applicable factors, organisations could improve customer satisfaction.

Thirdly, competition factors include the threat of competition in the market place, a lack of competition and the behaviour of competitors. In terms of the threat of competition, OEMs might, for example, choose to enter the remanufacturing market to prevent other competitors to profit from their returns (Ferguson \& Toktay 2006:352). However, the lack of competition could also influence disposition decisions, where the organisation might consider a number of disposition options because of a smooth market (Hazen et al. 2012:260). These considerations could lead to a number of business opportunities.

Fourthly, market-specific factors included market cannibalisation, conditions, position, potential, requirements and size. For instance, Rogers et al. (2013:43) stated that in order to avoid cannibalisation (old products compete with new ones in the same market), organisations might consider other alternative disposition options such as offshore secondary markets. Market position, size and conditions can also influence disposition decisions. For example, Khor et al. (2016:97) mentioned that if there is a lack of market options (limited markets), then organisations might find it the most beneficial to consider waste management practices. However, waste management practices result in no value for organisations, which could have a negative impact on organisational performance.

Finally, the industry in which an organisation operates has an influence in deciding on specific disposition options. For example, if organisations operate in the electronic industry, the disposition options will be different from those that operate in the fashion and apparel industry.

Organisations such as OEMs that want to enter the remanufacturing industry should particularly focus on the market-related factors. For instance, Hazen et al. (2012:259) found that remanufacturing organisations should consider factors such as the overall market size, market position and current and potential competition, such as the number of competing remanufacturers. In conclusion, market-related factors are important considerations for manufacturing organisations.

\section{Product-related factors}

Product-related factors are associated with product characteristics, condition and price. Firstly, in terms of product characteristics, two examples emerged from the content analysis. Bazan et al. (2015:315) mentioned that the obsolescence rate of a product would have an influence on disposition decisions. Other authors or scholars refer to obsolescence as the 'shelf life' of a product. If the product has a shorter shelf life or faster obsolescence rate, certain disposition options would not be feasible, especially those that require more effort and time such as remanufacturing and recycling.

Secondly, the condition of a product could also influence disposition decisions. For instance, if the product is in a good condition, then reuse or repair will be the best choice for an organisation. Closely related to product condition is product quality. It emerged from the content analysis that product 
TABLE 2: Categories and subcategories of factors that influence disposition decisions.

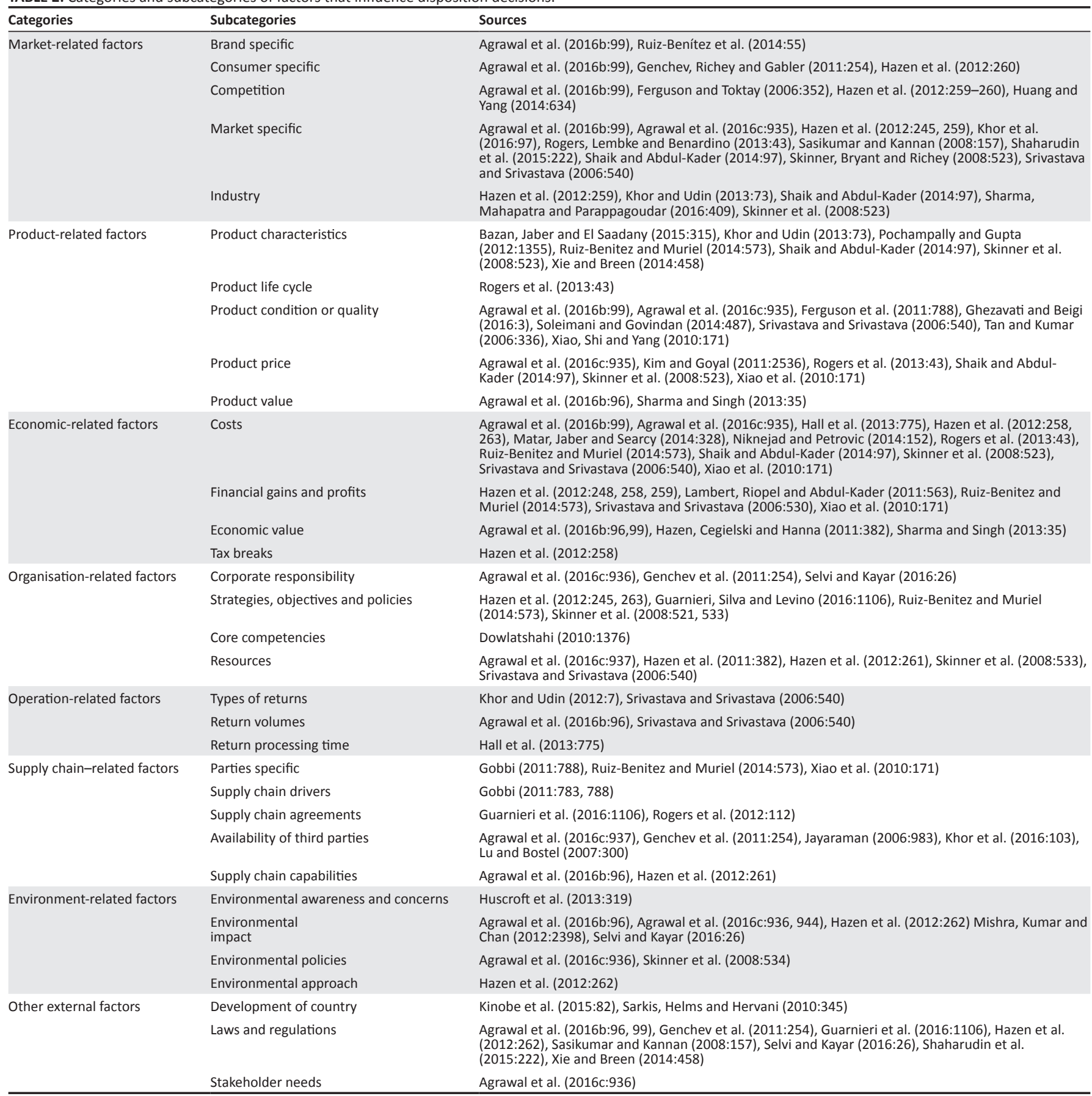

Note: Please see the full reference list of the article, Badenhorst, A., 2018, 'What practice can learn from theory: The potential impact of disposition decision factors on organisational performance', Journal of Transport and Supply Chain Management 12(0), a338. https://doi.org/10.4102/jtscm.v12i0.338, for more information.

quality could play a role before, in between and/or after disposition activities. Therefore, all aspects of product quality and condition will have an impact on disposition decisions, including the quality of the product originally sold to customers and the quality of the product after disposition. Not only do these factors have an influence on the disposition decision but also customer satisfaction of the recovered product.

Thirdly, product price can also consist of price before disposition and price after disposition. Furthermore, a number of authors or scholars mentioned that along with the selling price of a product, product value would also have an influence on disposition decisions. For instance, more expensive and higher value products have different disposition option decisions than that of lower value and priced products. In terms of the product price and value after disposition, Kim and Goyal (2011:2536) explained that if the price of the recovered product is not enough to support the validity of the disposition option, it should be excluded from the disposition decision.

Finally, product life cycle also emerged as an important factor. Rogers et al. (2013:43) mentioned that disposition decisions of mature products nearing the end of their life cycle will be different from new product introductions. 
Shelf life, the condition, quality and price of the product will have an influence on disposition decisions in all organisations, including retail and manufacturing businesses. More cumbersome, expensive and time-consuming recovery options will be selected if the product has a long life cycle and is of good quality, expensive and thus valuable.

\section{Economic-related factors}

Economic-related elements are often cited as important considerations for effective disposition decisions. This is mainly because of organisations focussing on costs and profitability. Firstly, it emerged that organisations need to determine all the costs associated with disposition. For instance, organisations should consider direct costs of disposition options, such as costs of landfill (disposal costs) and reverse logistics costs, such as costs of transportation, shipping and inspection costs. Furthermore, organisations should consider their overall objectives and strategies regarding costs. For instance, if a lean strategy is followed by an organisation, cost effectiveness is the overall driving force in decision-making. Therefore, more emphasis is placed on economic-related elements.

Secondly, in terms of profitability, it emerged from the content that organisations should not only look at the costs of each disposition option but also consider the financial gains that could be realised after disposition. Therefore, organisations should consider the highest return on the investment (cost) of the disposition option (income generated by that option minus cost).

Finally, the remaining economic-related factors included potential value and tax breaks. Closely related to profitability is potential economic value. It emerged that organisations should focus on the most value-producing option first, such as reuse with the highest recovery value. Therefore, organisations could enhance their financial performance related to recovery. Tax breaks are mainly associated with recovery of materials and products that has an environmental impact. Some authorities have environmental regulations in place and if organisations comply with regulations and implement environmentally friendly activities, tax breaks are possible. Considering this factor could lead to improved financial and environmental performance.

In reviewing the content of this category of factors, it became clear that economic-related factors should be considered by all organisations throughout the supply chain. Therefore, these factors are not organisational or industry-specific factors.

\section{Organisation-related factors}

This category relates to internal organisational and managerial factors such as corporate social responsibility, organisational strategies, objectives and policies, core competencies and resources. Firstly, the organisation's sincerity with corporate social responsibility could have an impact on disposition decisions. For example, if the organisation decides to take recycling serious as part of its corporate social responsibility, it would need to prove it by, for example, initiating recycling operations. Such a commitment will influence future disposition decisions.

Secondly, organisational resources and capabilities are also important considerations for effective disposition. For instance, Lu and Bostel (2007:300) mentioned that a manufacturing organisation would keep remanufacturing activities internal because of product knowledge and specialisation. Therefore, if the organisation has the resources to remanufacture a product, it might be more feasible to choose remanufacturing (Hazen et al. 2012:261). This could also result in a competitive advantage as well as cost efficiencies. On the other hand, if the organisation lacks the resources and capability for remanufacturing, then the organisation should consider other alternatives.

Finally, in terms of organisational strategies, objectives and policies, a number of considerations emerged. For instance, Skinner et al. (2008:533) stated that for effective disposition decisions, organisations should ask key questions such as: (1) Is the organisation's primary objective financial? and (2) is the organisation more service or operationally focussed? (refer to economic factors above). Similarly, organisations should also consider their policies for effective disposition decisions. For example, Hazen et al. (2012:262) stated that an organisation's environmental policy must correlate with its disposition strategy.

In conclusion, organisation-related factors need to be considered with disposition decision-making by all organisations, including manufacturers and retailers. For instance, as indicated above, a manufacturer should take its resources and capabilities into account to choose certain disposition options such as remanufacturing. On the other hand, if a retailer wants to convey a 'green' image (a corporate strategy), it might promote recycling and encourage consumers to return empty containers and make facilities for recycling (e.g. glass) available.

\section{Operation-related factors}

Operational factors are associated with the type of returns, volume of returns and the processing time of disposition operations. Firstly, the type of returns could link with productrelated elements, such as product characteristics. For example, service returns mostly relate to the repair option, while end-of-life returns would include remanufacturing and recycling.

Secondly, Agrawal et al. (2016b:99) stated that the number of returned products available for disposition is important in disposition decision-making. For example, organisations might have too low return volumes to warrant options such as remanufacturing, then other alternatives might have to be considered. Certain disposition options require high-volume returns to be feasible. For instance, repair, recycling and remanufacturing all require high return volumes. Therefore, 
economies of scale associated with disposition options is an important consideration.

Finally, return processing time emerged from the content but to a limited extent. Some options such as remanufacturing and recycling might take a longer time to process than other options such as repair and refurbishment.

Based on the findings, it can be concluded that organisations in different parts of a supply chain, for example retailers and manufacturers, should consider operation-related factors. For instance, if a consumer returns a defective electronic product, a retailer should base its disposition on the type of return and product condition. On the other hand, a manufacturer might exclude remanufacturing or recycling from its disposition decision because of low return volumes.

\section{Supply chain-related factors}

Supply chain-related factors include the specific factors of the supply chain parties, supply chain drivers, the availability of third parties, supply chain agreements and supply chain capabilities.

Firstly, the factors associated with supply chain parties include the power and relationships of parties in the chain. Although the power of parties might not have a direct influence, it could still have an impact on effective disposition decisions. For instance, Xiao et al. (2010:171) and Ruiz-Benitez and Muriel (2014:573) mentioned that large retailers normally transfer costs and disposition processes to smaller manufacturers. In this case, the responsibility of disposition decision-making would be the responsibility of the manufacturer, which will also relate to supply chain party relationships. In some situations, a retailer's disposition options of consumer returns will depend on the expectations of the manufacturer. For instance, in the case of large multinational manufacturers and distributors, small retailers will have no say in disposition options such as in the cellular phone supply chain.

Secondly, the supply chain drivers could also have an impact on effective disposition decisions. Gobbi (2011:783) provided two examples. Firstly, if the supply chain is legislationdriven, recycling will be the likely disposition decision. Alternatively, if the supply chain is value-driven, different product upgrade options such as repair and refurbishment would be more feasible.

Thirdly, the availability of third parties should also be considered. This would link to organisational resources and capabilities. If the organisation lacks the resources and capability for disposition options, outsourcing could be an important consideration. This, however, depends on the availability of capable third parties in the supply chain. For example, if a number of third parties specialise in recycling, then it should be considered as a viable option. This may result in cost savings and improved reverse logistics performance, because these third parties specialise in recovery activities.
Fourthly, supply chain agreements could play a role. There might be a possibility that parties have an agreement to share certain disposition responsibilities. For example, the manufacturer might allow the retailer to undertake repair operations but require that any products beyond repair be sent back to the manufacturer. In this case, the retailer might only carry out repairs based on the agreement with the manufacturer.

Finally, supply chain capabilities could link to resources of organisations and the availability of third parties. For example, if the retailer has the capability and resources to carry out repair operations, repair will form part of its disposition decisions. However, if the retailer lacks the capabilities and resources to perform refurbishment, other parties within the supply chain might have to carry out refurbishment operations. On the other hand, if no party in the supply chain has the capability to refurbish returned products, other alternatives should be considered.

With the supply chain management approach, it makes sense that organisations collaborate when making disposition decisions. However, power, drivers, agreements and capabilities might influence the disposition decisions in the supply chain.

\section{Environment-related factors}

Environmental factors are associated with environmental awareness and concerns, impact, environmental policies and approaches. Firstly, in terms of environmental awareness and concerns, it emerged that environmental awareness on the part of the organisation as well as the society could lead to disposition decisions other than waste management and disposal. Similarly, environmental impact could also lead to organisations to seek alternatives other than disposal. For example, some of the product upgrade options include replacement of parts, so organisations should determine the waste that could be generated during each disposition option.

Secondly, environmental policies could be either internal, such as organisational policies, or external such as environmental laws and policies of government. For instance, in South Africa, the Strategic Plan of the Department of Environmental Affairs (2012:13) included the aim of improving waste management in terms of disposal and recycling practices. Therefore, organisations need to consider internal and external environmental policies when making disposition decisions.

Finally, environmental approach directly relates to organisational strategies and policies. Hazen et al. (2012:262) provided an example differentiating between a reactive approach and proactive approach. In a reactive approach, organisations will abide by environmental regulations, and in a proactive approach, organisations will anticipate future regulations. In both cases, organisations could contribute to environmental protection and conservation of resources.

All organisations in a supply chain should consider environment-related factors. For instance, if one organisation 
within a supply chain has a proactive approach to the environment, it could influence the disposition decisions of the other members of the supply chain. Alternatively, the environmental policies of the government could also be applicable to all organisations within the supply chain. Ultimately, by considering these factors, organisations in a supply chain could improve their environmental performance.

\section{Other external factors}

Other external factors include the development of a country, laws, regulations and stakeholder needs. Firstly, in terms of the development of a country, two examples emerged from the content analysis. For instance, Kinobe et al. (2015:82) mentioned that incineration is inappropriate in developing countries because of the high costs associated with it. Sarkis et al. (2010:345) stated that developing countries might benefit from recycling activities for job creation purposes. Therefore, considering this factor could enhance the national economy of a country.

Secondly, laws and regulations also emerged strongly from the content analysis. Managers of organisations should be aware of the laws and regulations of a country when making disposition decisions. One example was provided by Agrawal et al. (2016b:99), stating that in some countries, legislation prevents organisations from disposing of end-oflife products, such as in the case of extended producer responsibility (EPR) regulations. In some sectors in South Africa, there are governmental strategies and regulations related to product disposition, such as compulsory environment rehabilitation in the mining sector.

Finally, stakeholder needs could also influence disposition decisions. Stakeholders include parties such as workers, customers, suppliers, shareholders and the community. Customers or consumers and suppliers can be linked to the categories of influencing factors already discussed above. However, other stakeholders' needs could also have an impact on disposition decisions. For example, organisations might operate in societies that focus on environmental awareness, which could result in the exclusion of disposal as an option. It is evident that external factors could also influence disposition options in organisations and supply chains.

In conclusion, many factors (refer to Table 2) should be considered when making disposition decisions. These factors therefore determine the disposition option selected. Each disposition option holds certain potential benefits and can add value to organisations and supply chains. The following section will focus on these value-adding benefits.

\section{Value-adding benefits of disposition decisions}

The benefits associated with disposition decision factors indicate the value of it in terms of organisational performance. Six benefit categories emerged from the content including economic-related benefits, operation-related benefits, market-related benefits, environment-related, supply chain benefits and social benefits. Table 3 provides an overview of the categories and subcategories of the benefits that emerged.

Each of the benefit categories will be discussed in the rest of this section.

\section{Economic-related benefits}

A number of economic benefits emerged from the content analysis. For instance, considering appropriate disposition decision factors could result in cost savings, improved financial performance, improved asset recovery, increased profitability and revenue generation. Firstly, Huang and Yang (2014:634) indicated that economic benefits could be realised through considering the disposition decisions made

TABLE 3: Categories and subcategories of benefits associated of disposition decisions.

\begin{tabular}{|c|c|c|}
\hline Categories & Subcategories & Sources \\
\hline $\begin{array}{l}\text { Economic-related } \\
\text { benefits }\end{array}$ & $\begin{array}{ll}\text { - } & \text { Cost savings or } \\
& \text { reductions } \\
\text { - } & \text { Profitability } \\
\text { - } & \text { Improve asset recovery } \\
\text { - Improve financial } \\
\text { - } & \text { performance } \\
\quad & \text { Recapture economic } \\
\text { - } & \text { Revenue generation } \\
\text { - } & \text { Cost efficiency }\end{array}$ & $\begin{array}{l}\text { Agarwal et al. (2016d:3), Agrawal } \\
\text { et al. (2016a:24), Agrawal et al. } \\
\text { (2016c:936, 942), Alinovi, Bottan } \\
\text { and Montanari (2012:1243), } \\
\text { Chan et al. (2012:1320), Genchev } \\
\text { (2009:146), Gobbi (2011:772), } \\
\text { Hahler and Fleischmann } \\
\text { (2013:2), Hazen et al. } \\
\text { (2012:258), Huang and Yang } \\
\text { (2014:634), Janse, Schuur and } \\
\text { De Brito (2010:502), Khor et al. } \\
\text { (2016:97), Khor and Udin } \\
\text { (2012:4), Lai, Wu and Wong } \\
\text { (2013:113), Lee and Lam } \\
\text { (2012:585), Mukhopadhyay and } \\
\text { Setaputra (2011:5318), Partida } \\
\text { (2011:63), Selvi and Kayar } \\
\text { (2016:19), Shaharudin et al. } \\
\text { (2015:222), Stock and Mulki } \\
\text { (2009:51), Ye et al. (2013:134) }\end{array}$ \\
\hline $\begin{array}{l}\text { Operation-related } \\
\text { benefits }\end{array}$ & $\begin{array}{ll}\text { - } & \text { Control returns } \\
\text { Improved reverse } \\
\text { - } & \text { logistics performance } \\
& \text { Improved operational } \\
& \text { performance } \\
\text { - } & \text { Reduce impact of } \\
& \text { product returns } \\
\text { - } & \text { Reduce inventory } \\
\text { - } & \text { Preserving inventory }\end{array}$ & $\begin{array}{l}\text { Agrawal et al. (2016c:944), } \\
\text { Bernon and Cullen (2007:52), } \\
\text { Eskandarpour et al. (2014:1394), } \\
\text { Genchev (2009:146), Lai et al. } \\
\text { (2013:113), Partida (2011:63), } \\
\text { Skinner et al. (2008:523) }\end{array}$ \\
\hline $\begin{array}{l}\text { Market-related } \\
\text { benefits }\end{array}$ & $\begin{array}{ll}\text { - } & \text { Sales growth } \\
& \text { Expansion of market } \\
& \text { share } \\
\text { - } & \text { New markets } \\
\text { - } \quad \text { Competitive advantage } & \text { Improved customer } \\
& \text { satisfaction }\end{array}$ & $\begin{array}{l}\text { Alinovi et al. (2012:1243), Hazen } \\
\text { et al. (2012:258), Khor et al. } \\
\text { (2016:104), Khor and Udin } \\
(2012: 12) \text {, Lee and Lam } \\
(2012: 585)\end{array}$ \\
\hline $\begin{array}{l}\text { Environment-related } \\
\text { benefits }\end{array}$ & $\begin{array}{ll}\text { - } & \text { Improved environmental } \\
\text { - } & \text { performance } \\
\text { - } & \text { Conste reduction } \\
& \text { resources } \\
\text { - } \quad \text { Ecologically friendly } \\
\text { - } \quad \text { Environmental } \\
\text { protection } \\
\text { - Compliance with } \\
\text { environmental } \\
\text { regulations }\end{array}$ & $\begin{array}{l}\text { Agrawal and Choudhary } \\
\text { (2014:19), Agrawal et al. } \\
\text { (2016c:936, 942), Ayvaz, Bolat } \\
\text { and Aydin (2015:402), Bazan } \\
\text { et al. (2015:308), Huang and } \\
\text { Yang (2014:634), Khor et al. } \\
\text { (2016:104), Khor and Udin } \\
\text { (2012:4), Lai et al. } \\
\text { (2013:113,114), Mahapatra, } \\
\text { Biswal and Mohanty (2013:52), } \\
\text { Mishra et al. (2012:2398), Ravi } \\
\text { and Shankar (2015:882), } \\
\text { Sasikumar, Kannan and Haq } \\
\text { (2010:1224), Sasikumar and } \\
\text { Kannan (2008:155), Zhou, Naim } \\
\text { and Wang (2007:66) }\end{array}$ \\
\hline $\begin{array}{l}\text { Supply chain } \\
\text { benefits }\end{array}$ & $\begin{array}{l}\text { - Improved supply chain } \\
\text { party relationships }\end{array}$ & $\begin{array}{l}\text { Agarwal et al. (2016d:3), Gobbi } \\
\text { (2011:772) }\end{array}$ \\
\hline Social benefits & $\begin{array}{ll}\text { - } & \text { Enhanced social } \\
\text { - } & \text { performance } \\
\text { Improved stakeholder } \\
\text { relationship } \\
\text { - Job creation } \\
\text { - Enhance national } \\
\text { economy }\end{array}$ & $\begin{array}{l}\text { Agrawal et al. (2016c:935), Lai } \\
\text { et al. (2013:113), Sarkis et al. } \\
\text { (2010:345), Selvi and Kayar } \\
(2016: 19)\end{array}$ \\
\hline
\end{tabular}

Note: Please see the full reference list of the article, Badenhorst, A., 2018, 'What practice can learn from theory: The potential impact of disposition decision factors on organisational performance', Journal of Transport and Supply Chain Management 12(0), a338. https://doi. org/10.4102/jtscm.v12i0.338, for more information. 
by competitors. This shows the importance of considering various factors when making disposition decisions.

In addition, it also emerged that all options except waste management could result in economic benefits. For instance, the reuse option is associated with transportation cost savings, while remanufacturing is associated with production cost savings and recycling associated with disposal cost savings. Therefore, organisations should also consider the economic benefits associated with each disposition option to improve financial performance.

Finally, Khor et al. (2016:97) stated that focussing on organisational strategies as a factor that influence disposition decisions could lead to improve decisionmaking, which could improve the overall profitability of the organisation.

\section{Operation-related benefits}

Some operational benefits emerged from the content analysis, which are mostly related to the reverse logistics process and product returns. For instance, it emerged that effective disposition decision-making can result in improved operational performance, better control over returns, improved reverse logistics performance, reduced impact of product returns and reduced or preserved inventory. This is largely because of greater understanding and planning associated with disposition decision-making. This indicates that a number of factors should be considered in order to realise operational benefits.

In addition, operational benefits could also be associated with choosing specific disposition options. For instance, the reuse option is associated with preserving inventory, while remanufacturing and refurbishment can enhance operational performance. Therefore, considering operationrelated disposition decision factors could result in operational improvements.

\section{Market-related benefits}

Market-related benefits are mostly associated with expansion of markets and sales growth, competitiveness and improved customer satisfaction. For instance, in remanufacturing, organisations can expand their business into alternative markets, which will lead to sales growth. In addition, Khor and Udin (2012:12) stated that by expanding markets, organisations would experience economic benefits and a competitive advantage, which could offset the possibility of internal cannibalisation. Therefore, through effective disposition decisions, organisations can have a competitive advantage through reselling and remarketing of recovered products. In addition, effective disposition decisions could enable organisations to create value for customers, which may lead to customer satisfaction (Lee \& Lam 2012:595). Essentially, marketing benefits could be linked to marketingrelated factors as well as economic-related factors. These benefits would lead to improved market and financial performance.

\section{Environment-related benefits}

In terms of the environmental benefits, some authors or scholars also mentioned that this is an important outcome of considering certain disposition decision factors. Various environmental benefits emerged from the content analysis including improved environmental performance, waste reduction and conservation of resources. For instance, Khor and Udin (2012:4) stated that effective disposition decisionmaking enables organisations to become environmentally responsible through sound disposition practices.

It was evident from these findings that environmental benefits could be linked to disposition decisions related to the environment. However, by considering other factors such as laws and regulations of government, organisations could also realise environmental benefits. Therefore, through effective disposition decisions, organisations can improve overall environmental performance.

\section{Supply chain benefits}

Limited authors or scholars mentioned the supply chain benefits that could be realised through effective disposition decisions. However, it did emerge that supply chain relationships could improve when considering supply chain-related factors. For instance, considering supply chain party needs could enhance supply chain performance. In addition, by collaborating on disposition decisions, all parties could experience improved supply chain relationships. These benefits could therefore improve organisational performance as well as supply chain performance.

\section{Social benefits}

A few social benefits also emerged from the content analysis. These benefits are mostly associated with stakeholders such as the society in which the organisation operates. An example of social benefits included job creation. For instance, recycling operations require labour, which lead to job creation. In addition, it also emerged that improved stakeholder relationships could be realised, specifically in terms of considering consumer needs as well as the needs of societies when making disposition decisions.

Finally, it emerged that through effective disposition decisions, an organisation can also enhance the national economy of a country. Essentially, effective disposition can enhance an organisation's social performance and be associated with corporate social responsibility. In addition, sustainability and ecologically friendly activities would benefit the society in which the organisation operates.

From the findings, it is evident that an organisation can enhance its performance by considering the disposition decision factors when making disposition decisions. It is therefore important to understand the factors required for effective disposition decisions to realise value-adding benefits, which can lead to improved organisational performance. 


\section{Framework on the impact of disposition decision factors on organisational performance}

The aim of this article was to demonstrate the potential impact of disposition decision factors on organisational performance. In order to establish a link between the findings, a conceptual framework was created to link the different disposition decision factors with the value-adding benefits and performance improvement areas. Table 4 provides the conceptual framework of the impact of disposition decisions factors on organisational performance.

It is evident from the conceptual framework that certain benefits and performance improvement areas could be linked to different disposition decision factors. Certain observations could be made from the conceptual framework.

Firstly, it seems that by considering organisational strategies, goals and policies are the most important considerations, because it could enhance organisations' financial performance, operational performance, market performance as well as environmental performance. In addition, it is also important to consider the product condition and quality, because these factors could enhance financial performance, operational performance and market performance.

Secondly, certain performance improvement areas could be associated with a number of disposition decision factors. Earlier it was mentioned that organisations should consider their overall goals when making disposition decisions. Similarly, organisations need to identify the performance areas that require improvement. Therefore, by focussing on specific performance areas, organisations should focus on specific factors associated with performance areas.

For instance, if the organisation wants to improve its operational performance, it can focus on product-related factors, operation-related factors and organisational policies. On the other hand, if an organisation seeks to improve financial performance, emphasis should be placed on economic-related factors. However, other factors should also

TABLE 4: Conceptual framework of the impact of disposition decision factors on organisational performance.

\begin{tabular}{|c|c|c|c|}
\hline Factors & Factor subcategories & Benefits & Performance improvements \\
\hline \multirow[t]{4}{*}{ Market-related factors } & Brand specific factors & $\begin{array}{l}\text { Market-related benefits: } \\
\text { - Competitive advantage } \\
\text { Economic-rowth } \\
\text { Econoled benefits: } \\
\text { - Profitability }\end{array}$ & $\begin{array}{l}\text { - } \quad \text { Market performance } \\
\text { Financial performance }\end{array}$ \\
\hline & Consumer-related factors & $\begin{array}{l}\text { Market-related benefits: } \\
\text { - Improved customer satisfaction }\end{array}$ & - Market performance \\
\hline & Competitive factors & $\begin{array}{l}\text { Market-related benefits: } \\
\text { - } \quad \text { Expansion of market share } \\
\text { - } \quad \text { Nempetitive advantage } \\
\text { - } \quad \text { Sales growth } \\
\text { Economic-related benefits: } \\
\text { - } \quad \text { Profitability } \\
\quad \text { Revenue generation }\end{array}$ & $\begin{array}{l}\text { - } \quad \text { Market performance } \\
\text { - Financial performance }\end{array}$ \\
\hline & Market-specific factors & $\begin{array}{l}\text { Market-related benefits: } \\
\text { New markets } \\
\text { Economic-related benefits: } \\
\text { - Profitability }\end{array}$ & $\begin{array}{l}\text { - } \quad \text { Market performance } \\
\text { - } \quad \text { inancial performance }\end{array}$ \\
\hline \multirow[t]{3}{*}{ Product-related factors } & Product characteristics & $\begin{array}{l}\text { Operation-related benefits: } \\
\text { - } \quad \text { Improved returns } \\
\text { Improved logistics performance }\end{array}$ & - Operational performance \\
\hline & Product condition or quality & $\begin{array}{l}\text { Economic-related benefits: } \\
\text { Opecapture economic value } \\
\text { Operation-related benefits: } \\
\text { - Control returns } \\
\text { Market-roved reverse logistics performance } \\
\text { Manefits: } \\
\text { - Improved customer satisfaction }\end{array}$ & $\begin{array}{l}\text { - } \quad \text { Financial performance } \\
\text { Operational performance } \\
\quad \text { Market performance }\end{array}$ \\
\hline & Product price and value & $\begin{array}{l}\text { Economic-related benefits: } \\
\text { - Improve financial performance } \\
\text { Operation-related benefits: } \\
\text { - Control returns } \\
\text { - Reduce impact of product returns }\end{array}$ & $\begin{array}{l}\text { - } \quad \text { Financial performance } \\
\quad \text { Operational performance }\end{array}$ \\
\hline \multirow[t]{4}{*}{ Economic-related factors } & Costs & $\begin{array}{l}\text { Economic-related benefits: } \\
\text { - } \quad \text { Profitability } \\
\text { - } \quad \text { Cost savings } \\
\text { Cost efficiency }\end{array}$ & - Financial performance \\
\hline & Profitability & $\begin{array}{l}\text { Economic-related benefits: } \\
\text { - } \quad \text { Profitability } \\
\text { - } \quad \text { Revenue generation } \\
\quad \text { economic value }\end{array}$ & - Financial performance \\
\hline & Economic value & $\begin{array}{l}\text { Economic-related benefits: } \\
\text { - Recapture economic value } \\
\text { - Improve asset recovery }\end{array}$ & - Financial performance \\
\hline & Tax breaks & $\begin{array}{l}\text { Economic-related benefits: } \\
\text { Environment-related benefits: } \\
\text { - Compliance with environmental regulations } \\
\text { - Ecologically friendly }\end{array}$ & $\begin{array}{l}\text { - } \quad \text { Financial performance } \\
\text { - Environmental performance }\end{array}$ \\
\hline
\end{tabular}


TABLE 4 (Continues...): Conceptual framework of the impact of disposition decision factors on organisational performance.

\section{Factors}

Organisation-related factors Corporate social responsibility

Resources and capabilities

Organisational strategies, objectives and policies

$\begin{array}{ll}\text { Operation-related factors } & \text { Type of return } \\ \text { Return volume } \\ \text { Return processing time } \\ \text { Supply chain factors } & \text { Supply chain parties }\end{array}$

Supply chain drivers

Availability of third parties

Supply chain agreements

Supply chain capabilities

Environment-related factors Environmental awareness and concerns

Environmental impact

Environmental policies

Benefits

Environment-related benefits:

- Ecologically friendly

- Enhance social performance

Economic-related benefits:

- Cost efficiencies

Market-related benefits:

Operation-related benefits:

- Control returns

Economic-related benefits:

- Cost savings

- Cost efficiency

- Profitability

Operation-related benefits:

- Improve reverse logistics performance

Market-related benefits:

- Improved customer satisfaction

Environment-related benefits:

- Compliance with environmental regulations

- Waste reduction

- Conservation of resources

Operation-related benefits:

- Control returns

- Reduce the impact of returns

- Improved reverse logistics performance

Economic-related benefits:

- Cost efficiency

Operation-related benefits:

- Control returns

- Improved reverse logistics performance

Operation-related benefits:

- Control returns

- Reduce the impact of returns

- Improved reverse logistics performance

Economic-related benefits:

- Cost savings

Supply chain benefits:

- Improve supply chain relationships

Economic-related benefits:

- Recapture economic value

Environment-related benefits

- Compliance with environmental regulations

Economic-related benefits:

- Cost savings

Operation-related benefits:

- $\quad$ Reduce the impact of returns

- $\quad$ Reduce the improved reverse logistics performance

- Reduce inventory

Operation-related benefits:

- Control returns

- Reduce the impact of returns

Improved reverse logistics performance

Supply chain benefits:

- Improve supply chain relationships

Operation-related benefits:

- Control returns

- Improved reverse logistics performance

Supply chain benefits:

- Improve supply chain relationships

Environment-related benefits:

- Waste reduction

- Improved environmental performance

- Conservation of resources

- Ecologically friendly

Social benefits:

- Enhance social performance

Environment-related benefits:

- Improved environmental performance

- Waste reduction

- Conservation of resources

- Ecologically friendly

- Environmental protection

Environment-related benefits:

- Improved environmental performance

- Waste reduction

- Conservation of resources

- Ecologically friendly

Environmental protection

Compliance with environmental regulations
Performance improvements

- Environmental performance

- Social performance

Market performance

- Operational performance

Financial performance

Operational performance

Market performance

- Environmental performance

- Operational performance

- Financial performance

- Operational performance

Financial performance

Supply chain performance

Financial performance

Environmental performance

Financial performance

- Operational performance$$
\text { Operational performance }
$$

Operational performance

- Supply chain performance

- Operational performance

- Supply chain performance

- Environmental performance
- Social performance

- Environmental performance

- Environmental performance

Table 4 continues on the next page $\rightarrow$ 
TABLE 4 (Continues...): Conceptual framework of the impact of disposition decision factors on organisational performance.

\begin{tabular}{|c|c|c|c|}
\hline Factors & Factor subcategories & Benefits & Performance improvements \\
\hline \multirow[t]{3}{*}{ Other external factors } & Development of the country & $\begin{array}{l}\text { Social benefits: } \\
\text { - } \quad \text { Enhanced social performance } \\
\text { - Job creation } \\
\quad \text { Enhance national economy }\end{array}$ & - Social performance \\
\hline & Laws and regulations & $\begin{array}{l}\text { Environment-related benefits: } \\
-\quad \text { Waste reduction } \\
\text { - } \quad \text { Ecolorvically friendly } \\
\text { - } \quad \text { Environmental protection } \\
\text { - Compliance with environmental regulations }\end{array}$ & - Environmental performance \\
\hline & Stakeholder needs & $\begin{array}{l}\text { Market-related benefits: } \\
\text { - Improved customer satisfaction } \\
\text { Supply chain benefits: } \\
\text { - Improve supply chain relationships } \\
\text { Social benefits: } \\
\text { - Enhanced social performance } \\
\text { - Improved stakeholder relationship }\end{array}$ & $\begin{array}{ll}\text { - } \quad \text { Market performance } \\
\text { - Supply chain performance } \\
\quad \text { Social performance }\end{array}$ \\
\hline
\end{tabular}

be considered, such as (1) market-related factors, including brand protection and competition, (2) organisation-related factors, such as organisational strategies and (3) supply chain-related factors such as supply chain drivers. This approach could be applied to all the performance areas and relevant disposition decision factors.

Finally, all organisations in the supply chain need to consider each performance improvement area associated with relevant disposition decision factors. It is also important that organisations recognise that by considering all the disposition decision factors, certain value-adding benefits could be realised. Furthermore, if organisations in the same supply chain collaborate when making disposition decisions, it could result in improved supply chain performance.

\section{Limitations and future research opportunities}

In this article, it has been established that there is a need to understand the importance of accurate disposition decisions. Firstly, this article was conceptual in nature and based on previously published research (67 articles). Therefore, it would be valuable to investigate performance improvement associated with disposition decision factors through empirical research. In addition, it was also established that there are limited publications focussing on the benefits of effective disposition decision-making, indicating that more research in this area is needed.

Secondly, this article was also not industry- or organisationspecific and it would be valuable to determine if the factors needed for effective disposition decisions differ from industry to industry or organisation to organisation.

Thirdly, the focus of this article was mostly on organisational performance improvement through effective disposition decisions. Therefore, it would be valuable to determine the impact of effective disposition decisions on supply chainwide performance.

Finally, there is a lack of research in South Africa in terms of product recovery or disposition in reverse logistics. It is therefore suggested that more empirical research is needed to determine if South African organisations need to consider the same or different disposition factors that were identified in this article.

\section{Conclusion}

A few research studies in reverse logistics have focussed on disposition decision factors especially in terms of the valueadding benefits and organisational performance. The aim of this study was to overcome this gap in research, by demonstrating the potential impact of disposition decision factors on organisational performance.

This article used a QCA methodology to identify the disposition decision factors and associated value-adding benefits. The content analysis was based on 67 scientific publications on reverse logistics between the years 2006 and 2016. Based on the findings, it was determined that a number of internal and external factors need to be considered to ensure effective disposition decisions. These include market-related, product-related, economic, organisational, operational, supply chain, environmental and other external factors. It was also determined that by considering these factors, organisations could realise a number of valueadding benefits. These included economic, operational, market-related, environmental, supply chain and social benefits.

Based on the findings of the QCA, a conceptual framework was developed demonstrating the impact of disposition decision factors on organisational performance. The framework showed that certain benefits are associated with certain disposition decision factors. In addition, the framework also demonstrated that certain disposition decision factors could be linked to certain organisational performance areas.

The conceptual framework developed in this study could help organisations to identify the factors that they have to consider to achieve improved organisational performance. In addition, the framework could also help organisations to become aware of the value-adding benefits associated with disposition decisions. Essentially, it is important for South African organisations to understand the importance of product recovery and reverse logistics practices. 


\section{Acknowledgements Competing interests}

The author declares that she has no financial or personal relationships that may have inappropriately influenced her in writing this article.

\section{References}

Abbasi, M. \& Nilsson, F., 2012, 'Themes and challenges in making supply chains environmentally sustainable', Supply Chain Management: An Internationa Journal 17(5), 517-530. https://doi.org/10.1108/13598541211258582

Agrawal, A. \& Choudhary, V., 2014, 'Reverse logistics: Performance measures and their effect in product lifecycle', International Journal Of Core Engineering \& Management 1(2), 14-22.

Agrawal, S., Singh, R.K. \& Murtaza, Q., 2015, 'A literature review and perspectives in reverse logistics', Resources, Conservation and Recycling 97, 76-92. https://doi. org/10.1016/j.resconrec.2015.02.009

Agrawal, S., Singh, R.K. \& Murtaza, Q., 2016a, 'Disposition decisions in reverse logistics: Graph theory and matrix approach', Journal of Cleaner Production 137, 93-104. https://doi.org/10.1016/j.jclepro.2016.07.045

Agrawal, S., Singh, R.K. \& Murtaza, Q., 2016b, 'Prioritizing critical success factors for reverse logistics implementation using fuzzy-TOPSIS methodology', Journal of Industrial Engineering International 12(1), 15-27. https://doi.org/10.1007/ s40092-015-0124-8

Agrawal, S., Singh, R.K. \& Murtaza, Q., 2016c, 'Disposition decisions in reverse logistics by using AHP-Fuzzy TOPSIS approach', Journal of Modelling in Management 11(4) 932-948. https://doi.org/10.1108/17465660710834453

Agarwal, V., Govindan, K., Darbari, J.D. \& Jha, P.C., 2016d, 'An optimization model for sustainable solutions towards implementation of reverse logistics under collaborative framework', International Journal of System Assurance Engineering and Management 7(4), 1-8. https://doi.org/10.1007/s13198-016-0486-3

Alinovi, A., Bottani, E. \& Montanari, R., 2012, 'Reverse logistics: A stochastic EOQ based inventory control model for mixed manufacturing/remanufacturing systems with return policies', International Journal of Production Research 50(5), 1243-1264. https://doi.org/10.1080/00207543.2011.571921

Atlas.ti., 2017, Rigor in qualitative and quantitative, viewed 08 March 2017, from http://atlasti.com/rigor-social-science-research/

Ayvaz, B., Bolat, B. \& Aydin, N., 2015, 'Stochastic reverse logistics network design for waste of electrical and electronic equipment', Resources, Conservation and Recycling 104, 391-404. https://doi.org/10.1016/j.resconrec.2015.07.006

Badenhorst, A., 2016, 'Prioritising the implementation of practices to overcome operational barriers in reverse logistics', Journal of Transport and Supply Chain Management 10(1), 1-12. https://doi.org/10.4102/jtscm.v10i1.240

Bazan, E., Jaber, M.Y. \& El Saadany, A.M.A., 2015, 'Carbon emissions and energy effects on manufacturing-remanufacturing inventory models', Computers and Industria Engineering 88, 307-316. https://doi.org/10.1016/j.cie.2015.07.002

Bernon, M. \& Cullen, J., 2007, 'An integrated approach to managing reverse logistics', International Journal of Logistics Research and Applications 10(January 2015), 41-56. https://doi.org/10.1080/13675560600717763

Bernon, M., Rossi, S. \& Cullen, J., 2011, 'Retail reverse logistics: A call and grounding framework for research', International Journal of Physical Distribution \& Logistics Management 41(5), 484-510. https://doi.org/10.1108/09600031111 138835

Bonev, M., 2012, Managing reverse logistics using system dynamics: A generic end-toend approach, Diplomica Verlag, Hamburg, viewed 28 October 2015, from https:// books.google.co.za

Chan, F.T.S., Chan, H.K. \& Jain, V., 2012, 'A framework of reverse logistics for the automobile industry', International Journal of Production Research 50(5), 1318-1331. https://doi.org/10.1080/00207543.2011.571929

Dehghanbaghi, M., Hosseininasab, H. \& Sadeghieh, A., 2016, 'A hybrid approach to support recovery strategies (A case study)', Journal of Cleaner Production 113, 717-729. https://doi.org/10.1016/j.jclepro.2015.11.064

Department of Environmental Affairs, 2012, Strategic plan 1 April 2012-31 March 2017, viewed 17 April 2017, from https://www.gov.za/sites/www.gov.za/files/ env_2012_2017_combined.pdf

Dowlatshahi, S., 2010, 'A cost-benefit analysis for the design and implementation of reverse logistics systems: Case studies approach', International Journal of Production Research 48(5), 1361-1380. https://doi.org/10.1080/00207540802552642

Ducharme, D., 2013, 'Using ATLAS.ti for content analysis', viewed 12 March 2017, from https://www.usnwc.edu/getattachment/Research---Gaming/War-Gaming/ Article ATLASti-for-Content-Analysis.pdf.aspx

Elo, S. \& Kyngäs, H., 2008, 'The qualitative content analysis process', Journal of Advanced Nursing62,107-115.https://doi.org/10.1111/j.1365-2648.2007.04569.x

Eriksson, P. \& Kovalainen, A., 2008, Qualitative methods in business research, Sage, London, viewed 10 August 2015, from https://books.google.co.za/

Eskandarpour, M., Masehian, E., Soltani, R. \& Khosrojerdi, A., 2014, 'A reverse logistics network for recovery systems and a robust metaheuristic solution approach', International Journal of Advanced Manufacturing Technology 74(9-12), 1393-1406. https://doi.org/10.1007/s00170-014-6045-7
Ferguson, M. \& Toktay, L.B., 2006, 'The effect of competition on recovery strategies', Production and Operations Management 15(3), 351-368. https://doi. org/10.1111/j.1937-5956.2006.tb00250.x

Ferguson, M.E., Fleischmann, M. \& Souza, G.C., 2011, 'A profit-maximizing approach to disposition decisions for product returns', Decision Sciences 42(3), 773-798. https://doi.org/10.1111/j.1540-5915.2011.00330.x

Friese, S., 2012, ATLAS.ti 7 Quick Tour, viewed 28 January 2015, from http://atlasti. com/wp-content/uploads/2014/05/QuickTour_a7_en_07.pdf

Friese, S., 2014, Qualitative data analysis with ATLAS, 2nd edn., Sage, London, viewed 10 August 2015, from https://books.google.co.za/

Gandolfo, A. \& Sbrana, R., 2008, 'Reverse logistics and market-driven management' Symphonya, Emerging Issues in Management 2(2008), 28-40.

Genchev, S.E., 2009, 'Reverse logistics program design: A company study', Business Horizons 52(2), 139-148. https://doi.org/10.1016/j.bushor.2008.09.005

Genchev, S.E., Richey, R.G. \& Gabler, C.B., 2011, 'Evaluating reverse logistics programs: A suggested process formalization', The International Journal of Logistics Management 22(2), 242. https://doi.org/10.1108/09574091111156569

Ghezavati, V.R. \& Beigi, M., 2016, 'Solving a bi-objective mathematical model for location-routing problem with time windows in multi-echelon reverse logistics using metaheuristic procedure', Journal of Industrial Engineering International 12(4), 469-483. https://doi.org/10.1007/s40092-016-0154-x

Gobbi, C., 2011, 'Designing the reverse supply chain: The impact of the product residual value', International Journal of Physical Distribution and Logistic Management 41(8), 768-796. https://doi.org/10.1108/09600031111166429

Gonçalves, M. \& Silva, Â., 2016, 'Reverse logistics: Systematic literature review vs companies' perspective', International Journal of Engineering and Industria Management 6, 67-86. http://hdl.handle.net/11067/2167

Govindan, K., Soleimani, H. \& Kannan, D., 2015, 'Reverse logistics and closed-loop supply chain: A comprehensive review to explore the future', European Journal of Operational Research 240(3), 603-626. https://doi.org/10.1016/j.ejor.2014. 07.012

Guarnieri, P., Silva, L.C. \& Levino, N.A., 2016, 'Analysis of electronic waste reverse logistics decisions using strategic options development analysis methodology: A Brazilian case', Journal of Cleaner Production 133, 1105-1117. https://doi. org/10.1016/j.jclepro.2016.06.025

Guo, W., 2010, 'Study on reverse logistics management of manufacturing enterprises', in Chinese Control and Decision Conference (CCDC 2010) Proceedings, May 26-28, Xuzhou, IEEE, pp. 925-929.

Hahler, S. \& Fleischmann, M., 2013, 'The value of acquisition price differentiation in reverse logistics', Journal of Business Economics 83(1), 1-28. https://doi. org/10.1007/s11573-012-0641-5

Hall, D.J., Huscroft, J.R., Hazen, B.T. \& Hanna, J.B., 2013, 'Reverse logistics goals, metrics, and challenges: Perspectives from industry', International Journal of Physical Distribution \& Logistics Management 43(9), 768-785. https://doi. org/10.1108/IJPDLM-02-2012-0052

Hazen, B.T., Cegielski, C. \& Hanna, J.B, 2011, 'Diffusion of green supply chain management', The International Journal of Logistics Management 22(3), 373-389. https://doi.org/10.1108/09574091111181372

Hazen, B.T., Hall, D.J. \& Hanna, J.B., 2012, 'Reverse logistics disposition decisionmaking', International Journal of Physical Distribution \& Logistics Management 42(3), 244-274. https://doi.org/10.1108/09600031211225954

Huang, Y. \& Yang, M., 2014, 'Reverse logistics innovation, institutional pressures and performance', Management Research Review 37(7), 615-641. https://doi. org/10.1108/MRR-03-2013-0069

Huscroft, J.R., Hazen, B.T., Hall, D.J., Skipper, J.B. \& Hanna, J.B., 2013, 'Reverse logistics: Past research, current management issues, and future directions', The International Journal of Logistics Management 24(3), 304-327. https://doi. org/10.1108/IJLM-04-2012-0024

Janse, B., Schuur, P. \& De Brito, M.P., 2010, 'A reverse logistics diagnostic tool: The case of the consumer electronics industry', International Journal of Advanced Manufacturing Technology 47(5-8), 495-513. https://doi.org/10.1007/s00170009-2333-z

Jayaraman, V., 2006, 'Production planning for closed-loop supply chains with product recovery and reuse: An analytical approach', International Journal of Production recovery and reuse: An analytical approach', International Journal of Product
Research 44(5), 981-998. https://doi.org/110.1080/00207540500250507

Khor, K.S. \& Udin, Z.M., 2012, 'Impact of reverse logistics product disposition towards business performance in Malaysian E \& E companies', Journal of Supply Chain and Customer Relationship Management 2012, 1-19. https://doi.org/10.5171/ 2012.699469

Khor, K.S. \& Udin, Z.M., 2013, 'Reverse logistics in Malaysia: Investigating the effect of green product design and resource commitment', Resources, Conservation and Recycling 81, 71-80. https://doi.org/10.1016/j.resconrec.2013.08.005

Khor, K.S., Udin, Z.M., Ramayah, T. \& Hazen, B.T., 2016, 'Reverse logistics in Malaysia: The contingent role of institutional pressure', International Journal of Production Economics 175, 96-108. https://doi.org/10.1016/j.ijpe.2016.01.020

Kim, T. \& Goyal, S.K., 2011, 'Determination of the optimal production policy and product recovery policy: The impacts of sales margin of recovered product' International Journal of Production Research 49(9), 2535-2550. https://doi.org/ 10.1080/00207543.2010.532918

Kinobe, J.R., Gebresenbet, G., Niwagaba, C.B. \& Vinnerås, B., 2015, 'Reverse logistics system and recycling potential at a landfill: A case study from Kampala city', Waste Management 42, 82-92. https://doi.org/10.1016/j.wasman.2015.04.012

Krippendorff, K., 2013, Content analysis: An introduction to its methodology, 3rd edn., Sage, Thousand Oaks, CA, viewed 15 July 2015, from https://books.google.co.za 
Lai, K.H., Wu, S.J. \& Wong, C.W.Y., 2013, 'Did reverse logistics practices hit the triple bottom line of Chinese manufacturers?', International Journal of Production Economics 146(1), 106-117. https://doi.org/10.1016/j.ijpe.2013.03.005

Lambert, S., Riopel, D. \& Abdul-Kader, W., 2011, 'A reverse logistics decisions conceptual framework', Computers and Industrial Engineering 61(3), 561-581. https://doi.org/10.1016/j.cie.2011.04.012

Lee, C.K.M. \& Lam, J.S.L., 2012, 'Managing reverse logistics to enhance sustainability of industrial marketing', Industrial Marketing Management 41(4), 589-598. https://doi.org/10.1016/j.indmarman.2012.04.006

Lu, Z. \& Bostel, N., 2007, 'A facility location model for logistics systems including reverse flows: The case of remanufacturing activities', Computers and Operation Research 34(2), 299-323. https://doi.org/10.1016/j.cor.2005.03.002

Mahapatra, R.N., Biswal, B.B. \& Mohanty, R.P., 2013, 'A modified reverse supply chain with remanufacturing for sustainable product cycle', International Journal of Supply Chain Management 2(2), 51-59.

Matar, N., Jaber, M. \& Searcy, C., 2014, 'A reverse logistics inventory model for plastic bottles', The International Journal of Logistics Management 25(2), 315-333. bottles', The International Journal of Logistic
https://doi.org/10.1108/IJLM-12-2012-0138

Mayring, P., 2014, Qualitative content analysis - Theoretical foundation, basic procedures and software solutions, Klagenfurt, viewed 28 August 2015, from procedures and software solutions, Klagenfurt, viewed
http://nbn-resolving.de/urn:nbn:de:0168-ssoar-395173

Mishra, N., Kumar, V. \& Chan, F.T.S., 2012, 'A multi-agent architecture for reverse logistics in a green supply chain', International Journal of Production Research 50(9), 2396-2406. https://doi.org/10.1080/00207543.2011.581003

Mukhopadhyay, S.K. \& Setaputra, R., 2011, 'Return policy in product reuse under uncertainty', International Journal of Production Research 49(17), 5317-5332. https://doi.org/10.1080/00207543.2010.523723

Niknejad, A. \& Petrovic, D., 2014, 'Optimisation of integrated reverse logistics networks with different product recovery routes', European Journal of Operational Research 238(1), 143-154. https://doi.org/10.1016/j.ejor.2014.03.034

Partida, B., 2011, 'Leaders show power of reverse logistics', Supply Chain Management Review 2011(November), 62-65

Pochampally, K.K. \& Gupta, S.M., 2012, 'Use of linear physical programming and Bayesian updating for design issues in reverse logistics', International Journal of Production Research 50(1), 1349-1359. https://doi.org/10.1080/00207543.2011. 571933

Pokharel, S. \& Mutha, A., 2009, 'Perspectives in reverse logistics: A review', Resources, Conservation and Recycling 53(4), 175-182. https://doi.org/10.1016/j. Conservation and $R$

Ravi, V. \& Shankar, R., 2015, 'Survey of reverse logistics practices in manufacturing industries: An Indian context', Benchmarking: An International Journal 22(5), 874-899. https://doi.org/10.1108/09564230910978511

Rogers, D.S., Lembke, R. \& Benardino, J., 2013, 'Reverse logistics: A new core competency', Supply Chain Management Review, May/June, 40-47, viewed January 2016, from http://www.scmr.com/article/reverse_logistics_a_new_core_competency

Rogers, D.S., Melamed, B. \& Lembke, R.S., 2012, 'Modeling and analysis of reverse logistics', Journal of Business Logistics 33(2), 107-117. https://doi. org/10.1111/j.0000-0000.2012.01043.x

Ruiz-Benítez, R., Ketzenberg, M. \& Van der Laan, E.A., 2014, 'Managing consume returns in high clockspeed industries', Omega 43, 54-63. https://doi. org/10.1016/j.omega.2013.06.004

Ruiz-Benitez, R. \& Muriel, A., 2014, 'Consumer returns in a decentralized supply chain', International Journal of Production Economics 147, 573-592. https://doi. org/10.1016/j.ijpe.2013.05.010

Santos, J.B. \& D'Antone, S., 2014, 'Reinventing the wheel ? A critical view of demandchain management', Industrial Marketing Management 43(6), 1012-1025. https://doi.org/10.1016/j.indmarman.2014.05.014

Sarkis, J., Helms, M.M. \& Hervani, A.A., 2010, 'Reverse logistics and social sustainability', Corporate Social Responsibility and Environmental Management 17(6), 337-354. https://doi.org/10.1002/csr.220

Sasikumar, P. \& Kannan, G., 2008, 'Issues in reverse supply chains, part I: End-of-life product recovery and inventory management-an overview', International Journal of Sustainable Engineering 1(3), 154-172. https://doi.org/10.1080/19397030802433860

Sasikumar, P., Kannan, G. \& Haq, A.N., 2010, 'A multi-echelon reverse logistics network design for product recovery - A case of truck tire remanufacturing', Internationa Journal of Advanced Manufacturing Technology 49(9-12), 1223-1234. https:// doi.org/10.1007/s00170-009-2470-4
Saunders, M., Lewis, P. \& Thornhill, A., 2012, Research methods for business student, 6th edn., Pearson Education, Harlow, UK.

Schreier, M., 2012, Qualitative content analysis in practice, Sage, London, viewed 30 July 2015, from https://books.google.co.za/

Schreier, M., 2014, 'Qualitative content analysis', in U. Flick (ed.), The SAGE handbook of qualitative data analysis, pp. 170-184, Sage, London, viewed 10 August 2015, from $\mathrm{http} / / /$ srmo.sagepub.com/view/the-sage-handbook-of-qualitative-data-analysis/ $\mathrm{n} 12 . \mathrm{xml}$

Selvi, M.S. \& Kayar, Y., 2016, 'Reverse logistics activities in enterprises and implementation reasons', International Journal of Research in Business \& Socia Science 5(1), 15-29. https://doi.org/10.20525/ijrbs.v5i1.46

Shaharudin, M.R., Zailani, S. \& Tan, K.C., 2015, 'Barriers to product returns and recovery management in a developing country: Investigation using multiple methods', Journal of Cleaner Production 96, 220-232. https://doi.org/10.1016/j. jclepro.2013.12.071

Shaik, M.N. \& Abdul-Kader, W., 2014, 'Comprehensive performance measurement and causal-effect decision making model for reverse logistics enterprise', Computers and Industrial Engineering 68(1), 87-103. https://doi.org/10.1016/j. cie.2013.12.008

Sharma, S. \& Singh, G., 2013, 'Reverse logistics: Design implications on the basis of product types sharing identical supply chain member motivations', Uncertain Supply Chain Management 1(1), 33-44. https://doi.org/10.5267/j.uscm.2013.05.001

Sharma, S.K., Mahapatra, S. \& Parappagoudar, M.B., 2016, 'Benchmarking of product recovery alternatives in reverse logistics', Benchmarking: An International Journal 23(2), 406-424. https://doi.org/10.1108/09564230910978511

Skinner, L.R., Bryant, P.T. \& Richey, R.G., 2008, 'Examining the impact of reverse logistics disposition strategies', International Journal of Physical Distribution \& Logistics Management, 38(7), 518-539. https://doi.org/10.1108/09600030 810900932

Soleimani, H. \& Govindan, K., 2014, 'Reverse logistics network design and planning utilizing conditional value at risk', European Journal of Operational Research 237(2), 487-497. https://doi.org/10.1016/j.ejor.2014.02.030

Srivastava, S.K. \& Srivastava, R.K., 2006, 'Managing product returns for reverse logistics', International Journal of Physical Distribution \& Logistics Management 36(7), 524-546. https://doi.org/10.1108/09600030610684962

Starostka-Patyk, M., Zawada, M., Pabian, A. \& Abed, M., 2013, 'Barriers to reverse logistics implementation in enterprises', in International Conference on Advanced Logistics and Transport (ICALT 2013) Proceedings, May 29-31, Sousse, pp. 506-511.

Stock, J.R. \& Boyer, S.L., 2009, 'Developing a consensus definition of supply chain management: A qualitative study', International Journal of Physical Distribution \& Logistics Management 39(8), 690-711. https://doi.org/10.1108/096000309 10996323

Stock, J.R. \& Mulki, J.P., 2009, 'Product returns processing: An examination of practices of manufacturers, wholesalers/distributors, and retailers', Journal of Business Logistics 30(1), 33-62. https://doi.org/10.1002/j.2158-1592.2009.tb00098.x

Şükrü, M., Akdoğan, M.Ş. \& Coşkun, A., 2012, 'Drivers of reverse logistics activities: An empirical investigation', Procedia-Social and Behavioral Sciences 58, 1640-1649. https://doi.org/10.1016/j.sbspro.2012.09.1130

Tan, A.W.K. \& Kumar, A., 2006, 'A decision-making model for reverse logistics in the computer industry', The International Journal of Logistics Management 17(3), 331-354. https://doi.org/10.1108/09574090610717518

Xiao, T., Shi, K. \& Yang, D., 2010, 'Coordination of a supply chain with consumer return under demand uncertainty', International Journal of Production Economics 124(1), 171-180. https://doi.org/10.1016/j.jpe.2009.10.021

Xie, Y. \& Breen, L., 2014, 'Who cares wins? A comparative analysis of household waste medicines and batteries reverse logistics systems', Supply Chain Management: An International Journal 19(4), 455-474. https://doi.org/10.1108/ SCM-07-2013-0255

Ye, F., Zhao, X., Prahinski, C. \& Li, Y., 2013, 'The impact of institutional pressures, top managers' posture and reverse logistics on performance - Evidence from China', International Journal of Production Economics 143(1), 132-143. https://doi. org/10.1016/j.ijpe.2012.12.021

Zhou, L., Naim, M. \& Wang, Y., 2007, 'Soft systems analysis of reverse logistics battery recycling in China', International Journal of Logistics Research and Application 10(1), 57-70. https://doi.org/10.1080/13675560600717847 